\title{
Rekjanleiki ígræða í skurðlækningum
}

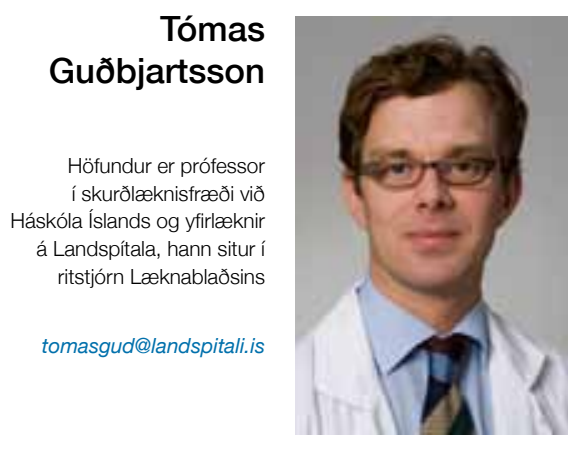

Á síðustu mánuðum hefur verið mikið fjallað um svokallaðar PIP-brjóstafyllingar sem rúmlega 400 íslenskar konur fengu á árunum 2000 til 2010. Í ljós kom að franska fyrirtækið Poly Implants Prothèses notaði ólöglegt iðnaðarsílíkon í fyllingarnar og blekkti evrópskar eftirlitsstofnanir sem veittu púðunum CE-vottun. Málið allt er hið vandræðalegasta fyrir hlutaðeigandi eftirlits- og heilbrigðisstofnanir, enda talið að allt að 300.000 konur hafi fengið slíkar brjóstafyllingar. Раð snýst reyndar um fleira en notkun iðnaðarsílíkons, pví komið hefur í ljós að leki er mun algengari frá pessum fyllingum en öðrum tegundum brjóstafyllinga. Pannig sýna bráðabirgðaniðurstöður á peim 154 konum sem ómskoðaðar hafa verið hér á landi á síðustu vikum að allt að 58\% PIP-fyllinganna leka. ${ }^{1}$ Ekki er vitað til pess að leki frá fyllingunu $m$ valdi alvarlegum sjúkdómum eins og til dæmis krabbameini. Engu að síður er ljóst að brjóst pessara kvenna geta aflagast og sílíkonleki getur valdið bólgu í brjóstum og holhandareitlum. ${ }^{2}$ Pví er mjög skiljanlegt að konur með pessar gölluðu brjóstafyllingar séu kvíðnar og vilji almennt láta fjarlægja pær sem fyrst. Par sem fyrirtækið sem framleiðir fyllingarnar er gjaldprota og eigandinn sætir lögreglurannsókn er að mínu mati eðlilegt að íslensk heilbrigðisyfirvöld bjóði pessum konum aðgerð par sem fyllingarnar eru fjarlægðar peim að kostnaðarlausu, óháð pví hvort pær leka eða ekki.

PIP-málið hefur komið af stað parfri umræðu um eftirlitshlutverk landlæknisembættisins og fleiri stofnana eins og
Lyfjastofnunar, og hversu vanmáttugar pessar stofnanir eru í eftirliti með læknastarfsemi utan sjúkrahúsa. Petta snýr ekki síst að skráningu ígræða (implants) en notkun peirra fer hratt vaxandi í skurðlækningum. Sem dæmi má nefna ísetningu gang- og bjargráða, hjartaloka ýmiss konar og nælonneta við kviðslitsaðgerðir. Flestar pessara aðgerða eru gerðar á sjúkrahúsum og pví hægt að rekja ígræði sem notuð eru í tölvuskrám sjúkrahúsa. Kviðslitsaðgerðir eru á meðal algengustu skurðaðgerða á einkastofum, en par sem Sjúkratryggingar Íslands taka pátt í kostnaði sjúklinga er unnt að afla upplýsinga um pær og pau ígræði sem notuð eru, ef nauðsyn ber til. Sjúkratryggingar taka hins vegar sjaldan pátt í kostnaði við brjóstastækkanir og skráning á notkun brjóstafyllinga hefur verið á ábyrgð lýtalækna sjálfra. Рað er óviðunandi að mínu mati og byggi ég pað mat mitt á nýjum og gömlum dæmum. Hin síðari ár hefur sífellt meiri áhersla verið lögð á skráningu fylgikvilla í skurðlækningum og tengingu peirra við ígræði. Pannig er hjartaloka sem grædd er í sjúklinga á Landspítala skráð með sérstöku framleiðslunúmeri í sjúkraskrá sjúklings, en sömu upplýsingar skráðar erlendis af framleiðanda lokunnar. Pessi nákvæma skráning kemur ekki til af góðu. Í lok áttunda áratugarins kom upp hönnunargalli í hjartaloku af Björk-Shiley gerð sem notuð hafði verið í mörg púsund sjúklinga. ${ }^{3}$ Pegar lokublöðin losnuðu urðu afleiðingarnar afdrifaríkar og skurðlæknum var pví fyrirskipað að hafa upp á sjúklingunum og í sumum tilfellum að skipta gölluðu lokunum út fyrir nýjar. Pessi reynsla varð til pess að skerpa mjög á eftirliti og skráningu lækningatækja og ígræða um allan heim. Enda pótt afleiðingar lekra PIP-fyllinga séu ekki jafn alvarlegar er hér augljós heilsuvá á ferðinni.

Af ofansögðu er ljóst að miðlæg skráning ígræða er nauðsynleg, jafnt í lýtalækningum sem öðrum sérgreinum skurðlækninga. Pess vegna veldur áhyggjum að lýtalæknar hafi nýlega neitað landlækni um upplýsingar um konur sem gengist höfðu undir brjóstastækkunaraðgerð. ${ }^{4}$ Ég tel vafasamt að bera par fyrir sig trúnaðarog pagnarskyldu gagnvart sjúklingum, enda er landlæknir líkt og aðrir læknar bundinn trúnaði við sjúklinga. Embættið hefur um árabil skráð viðkvæmar upplýsingar sem mikilvægt er að hafa aðgengi að, til dæmis um sjálfsvíg og voveifleg mannslát. Meti landlæknisembættið pað svo að vá sé fyrir hendi, parf landlæknir að geta haft samband við pá sjúklinga sem málið varðar. Slíkt eftirlitshlutverk á ekki að vera á ábyrð einstakra lækna sem sumir halda skrár um sjúklinga sína í einkatölvum. Í 7. grein laga um landlækni og lýðheilsu (nr. 41/2007) er skýrt tekið fram að landlæknisembættið skuli hafa eftirlit með heilbrigðispjónustu á landsvísu, jafnt innan sem utan sjúkrahúsa. Í sömu lög vantar hins vegar augljóslega úrræði til að beita viðurlögum, séu pessar upplýsingar ekki veittar. Hætt er við að úrskurður Persónuverndar, sem nú er með málið til umsagnar, geti flækt og tafið petta mál enn frekar. Verði pað raunin er brýnt að breyta lögunum pannig að enginn vafi leiki á valdheimildum landlæknisembættisins. Hér vega hagsmunir sjúklinga pyngst.

Skoðanir í pessum leiðara eru höfundar og ekki stjórnar Skurðlæknafélags Íslands par sem Tómas á sæti.

\section{Heimildir}

1. landlaeknir.is/Pages/1055?NewsID=2358 - febrúar 2012

2. The safety of PIP silicone breast implants. Scientific Committee on Emerging and Newly Identified Health Risks SCENIHR. European Commission (1st Version, Feb 1), Brussels 2012.

3. Blot WJ, Ibrahim MA, Ivey TD, Acheson DE, Brookmeyer $\mathrm{R}$, Weyman A, et al. Twenty-five-year experience with the Björk-Shiley convexoconcave heart valve: a continuing clinical concern. Circulation 2005: 111: 2850-7.

4. lis.is/lis/Frettir/nanar/5097/meira-um-pip-malid febrúar 2012.

The traceability of implants in surgery

Tomas Gudbjartsson, Professor of Surgery and Cardiothoracic Surgeon, Landspitali University Hospital IS 101 Reykjavik, Iceland 